\title{
PENINGKATAN PRODUKSI PENGRAJIN USUK BAMBU DI DESA GUNUNGREJO SINGOSARI KABUPATEN MALANG
}

\author{
Dedi Usman Effendy ${ }^{1}$
}

\begin{abstract}
ABSTRAK
Pada dasarnya industri pengrajin usuk bambu yang berada di pinggiran kabupaten Malang yaitu tepatnya di dusun krewe Desa Gunungrejo Kecamatan Singosari Kabupaten Malang. Sebelum kemerdekaan yang silam sudah melakukan usaha usuk bambu ini, hanya dengan berbekal peralatan palu, linggis, pahat, kapak, dan sabit. Dengan bahan dasar bambu dapat di hasilkan usuk dan gedek. Pada dasarnya permasalahan yang dihadapai mitra dua aspek utama yaitu permasalahan produksi dan permasalahan manajemen adalah masalah proses penghalusan usuk bambu yang kurang bermutu dan membutukan waktu lama, masih menggunakan sistem pemasaran konvensional, masalah kendali mutu produk, belum dilakukan pembukuan yang tertib, arus kas masih tidak jelas, tidak ada neraca bulanan, dan sejenisnya, Target luaran dan solusi dari program ini adalah menghasilkan produk usuk bambu dengan kualitas yang lebih baik sehingga pengrajin lebih berkembang dan memiliki segmentasi pasar yang lebih luas, menghasilkan alat penghalus bambu yang dapat digunakan untuk menghaluskan bambu utuh menjadi usuk yang halus sehingga dalam pembuatan usuk bambu tidak menjadi kendala dalam proses produksi, menghasilkan sistem pengelolaan keuangan dalam pengrajin sehingga semua transaksi dapat tercatat dan ternalisa dengan baik.
\end{abstract}

Kata kunci : produksi, manajemen, mesin, bambu, usuk

\begin{abstract}
Basically the bamboo usuk craftsman industry located on the outskirts of Malang is precisely in the krewe hamlet of Gunungrejo Village, Singosari District, Malang Regency. Before the independence of the past this bamboo business had been usuk, only armed with hammer equipment, crowbars, chisels, axes, and sickles. With the basic ingredients of bamboo, you can produce rakes and steam. Basically, the problems faced by partners are two main aspects, namely production problems and management problems, namely the problem of refinement of bamboo chips which are of poor quality and take a long time, still use conventional marketing systems, product quality control issues, have not been carried out in an orderly manner, cash flow is still not clearly, there is no monthly balance sheet, and the like, the target of the output and the solution of this program is to produce bamboo rafters with better quality so that the craftsmen are more developed and have a wider market segmentation, producing bamboo refiners that can be used to refine whole bamboo into a smooth rafting so that bamboo rafting is not an obstacle in the production process, resulting in a financial management system in the craftsman so that all transactions can be recorded and analyzed properly
\end{abstract}

Keywords: production, management, machinery, bamboo, usuk.

\section{PENDAHULUAN}

Bambu adalah tumbuhan alam yang mudah didapat baik di daerah pegunungan, hutan bahkan di daerah daratan pun terlihat dimana- mana. Namun siapa sangka bahwa bambu tersebut

\footnotetext{
${ }^{1}$ Program Studi Teknik Elektro, Fakultas Teknik, Universitas Widyagama Malang, dedy@widyagama.ac.id
} 
bila disentuh bagus lagi akan mendatangkan hasil yang dapat digunakan untuk kebutuhan dan keperluan hidup di masyarakat. Pengusul ambil contoh bambu dapat di buat jembatan, bambu dapat di pakai sebagai bahan bangunan ada gedek dan juga untuk usuk pembuatan rumah, bahkan rumahrumah dahulu di buat dari bahan bambu seperti terlihat banyak di desa-desa di Indonesia dsb. Pengrajin berbahan baku bambu ini sudah ada sejak jaman sebelum Indonesia merdeka dulu, meskipun demikian usaha ini jarang sekali diminati oleh masyarakat di jaman sekarang ini.

Pada dasarnya industri pengrajin usuk bambu yang berada di pinggiran kabupaten Malang yaitu tepatnya di dusun krewe Desa Gunungrejo Kecamatan Singosari Kabupaten Malang sekitar $75 \%$ masyarakat dari jumlah penduduk 1 RW 303 KK dan 6 RT. Sebelum kemerdekaan yang silam sudah melakukan usaha usuk bambu ini, hanya dengan berbekal peralatan palu, linggis, pahat, kapak, dan sabit. Dengan bahan dasar bambu dapat di hasilkan usuk dan gedek.

Rencana usulan kegiatan pengabdian yang akan dilakukan oleh Tim pelaksana diarahkan untuk memberikan solusi alternatif terhadap beberapa permasalahan yang dihadapi oleh Pengrajin usuk bambu Kabupaten Malang agar dapat berkembang dan mampu bersaing.

\section{Bahan Produksi}

Dari kondisi mitra usaha masih belum maksimal memanfaat dan menggunakan alat yang mampu meningkatkan kinerja produksi. Seperti yang tampak dalam Gambar, pekerja masih menggunakan sabit manual yang hasilnya masih kurang halus dan memakan waktu yang sangat lama. Sedangkan pada Gambar 2 menunjukkan aktifitas mitral yang sudah memproduksi usuk dengan peralatan manual tapi untuk mitral sudah cukup banyak usuk yang di produksi, Akan tetapi mitra 2 sama, semua peralatan manual semua tapi untuk kapasitas produksinya lebih sedikit.

Pada gambar produk tersebut menunjukkan bahwa diperlukan penggunaan alat yang mampu meningkatkan produktifitas dan mutu.

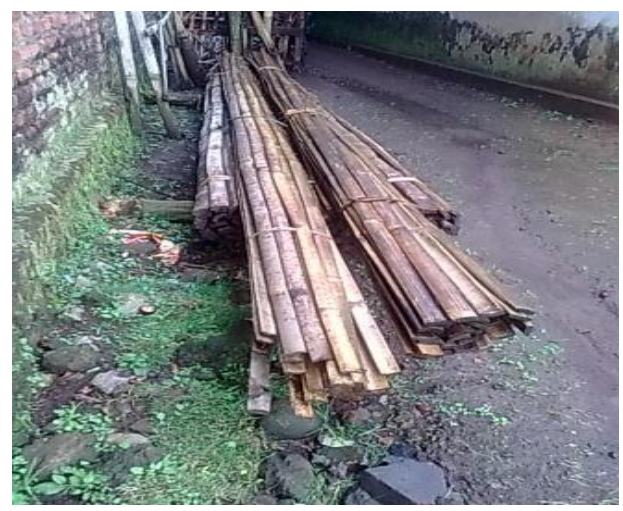

Gambar 1. Hasil Akhir Produksi

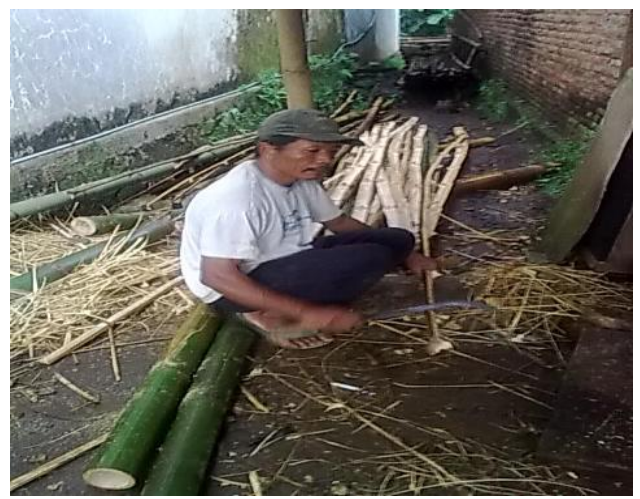

Proses Produksi

Gambar 2. Proses Produksi Usuk Manual

Berdasarkan pengalaman Pengrajin rata-rata dapat memproses 20 - 50 buah bambu untuk Pengrajin "GUNUNGREJO" dan 10 - 30 buah bambu untuk Pengrajin "SAMURI". Jumlah bahan 
baku bambu yang diproses setiap hari sangat bervariasi dan tidak bisa diprediksi secara pasti karena proses pembuatan usuk tergantung pada pesanan. Proses produksi pada masing-masing Pengrajin memiliki kesamaan. Alur produksi usuk bambu dijelaskan sebagai berikut :

1. Sekitar $20-50$ buah bambu dipersiapkan untuk diproses.

bambu petung/pringori yang akan diproses tanpa mengalami proses seleksi dan grading, sehingga ukuran bambu yang didapat bervariasi. Kondisi ini memberikan dampak yang cukup besar pada keseragaman produk akhir usuk bambu yang dihasilkan. Hal ini disebabkan karena bambu memiliki volume yang berbeda pada masing-masing bambu, sehingga apabila dibelahbelah dari bambu yang utuh akan memberikan hasil yang bervariasi.

2. bambu utuh di potong menjadi ukuran 4 meter dan 6 meter. Sebagai ukuran standart usuk bambu.

3. Pasca pemotongan bambu utuh, kulit luar bambu langsung dibersihkan supaya didapatkan usuk rata.

4. bambu yang sudah terpotong-potong dan bersih, langsung akan dibelah-belah sesuai dengan besar kecilnya bambu yang ada, bambu yang kecil akan dibelah menjadi 6 belah bagian usuk sedangkan bambu yang besar menjadi 8 belah bagian usuk dengan menggunakan sabit.

5. Dilanjutkan dengan penghalusan usuk bambu yang dilakukan dengan mengunakan sabit kecil untuk menghasilkan usuk yang halus.

6. Setelah usuk bambu diikat-ikat, maka persiapan untuk proses selajutnya yaitu proses perendaman di dalam air, yang biasanya ditempatkan di bak air atau disungai. Apapun proses perendaman usuk bambu ini, mempunyai jangka waktu yang agak lama yaitu minimal sekitar 4 minggu dan maksimal 6 minggu perendaman.

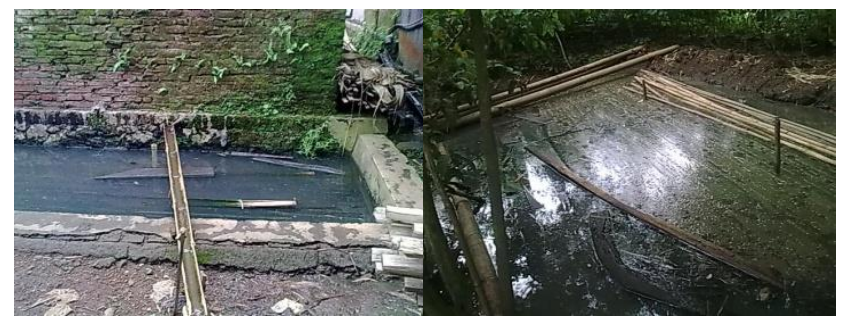

Gambar 3. Proses Perendaman Usuk Bambu

7. Proses perendaman selesai, maka usuk bambu dikeringkan sampai benar-benar kering, setelah kering usuk bambu siap untuk digunakan.

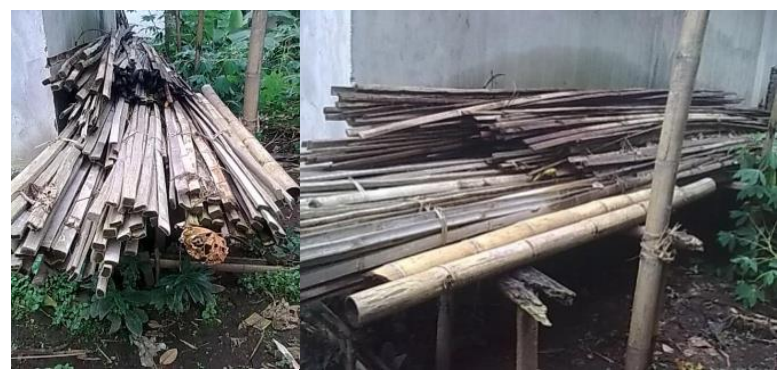

Gambar 4. Usuk Bambu Siap dipasarkan

8. Pasca pengeringan usuk bambu, dilanjutkan proses pengikatan usuk, yang mana setiap 1 ikat usuk bambu berisi 20 buah usuk dan dikirim ke pemesan

\section{Aspek Manajemen}

Sedangkan aspek manajemen, kondisi mitra secara garis besar juga masih sangat sederhana dan konvensional sehingga kemampuan untuk mengembanggkan usaha yang lebih besar masih sulit untuk dicapai. Secara rinci, kondisi mitra adalah sebagaimana terdapat pada Tabel 2. 
Tabel 2: Kondisi Aspek Manajemen Mitra

\begin{tabular}{|l|l|l|l|}
\hline No & \multicolumn{1}{|c|}{ Aspek kondisi } & Pengrajin "GUNUNGREJO" & \multicolumn{1}{|c|}{ Pengrajin "SAMURI" } \\
\hline 1 & Lama Usaha & 30 Tahun & 5 Tahun \\
\hline 2 & Stok Bahan baku & Stok yang dimiliki terbatas & $\begin{array}{l}\text { Stok yang dimiliki sangat } \\
\text { terbatas }\end{array}$ \\
\hline 3 & Cara Pembuatan & Dibuat berdasarkan pesanan & Dibuat berdasarkan pesanan \\
\hline 4 & Pengemasan & $\begin{array}{l}\text { Belum ada kemasan khusus, } \\
\text { diikat manual }\end{array}$ & $\begin{array}{l}\text { Belum ada kemasan khusus, } \\
\text { diikat manual }\end{array}$ \\
\hline 5 & Keberadaan user manual & Belum ada user manual & Belum ada user manual \\
\hline 6 & $\begin{array}{l}\text { Cara pemasaran dan } \\
\text { promosi }\end{array}$ & $\begin{array}{l}\text { Konvensional dan door to } \\
\text { door }\end{array}$ & $\begin{array}{l}\text { Konvensional dan door to } \\
\text { door }\end{array}$ \\
\hline 7 & Kendali mutu & $\begin{array}{l}\text { Masih belum di lakukan } \\
\text { dengan baik }\end{array}$ & Masih belum di lakukan \\
\hline 8 & Permodalan & $\begin{array}{l}\text { Sudah ada tapi sangat } \\
\text { terbatas }\end{array}$ & $\begin{array}{l}\text { Tidak punya modal yang } \\
\text { cukup }\end{array}$ \\
\hline 9 & Pembukuan keuangan & Belum dilakukan & Belum dilakukan \\
\hline
\end{tabular}

Kondisi aspek manajemen yang dilakukan Mitra secara operasional di lapangan adalah sebagai berikut:

1) Sistem pemasaran yang dilakukan masih dengan cara konvensional dengan door to door menawarkan ke penduduk desa maupun kota secara langsung. Setelah mendapatkan pesanan baru dibuatkan sesuai dengan banyaknya pesanan. Waktu yang dibutuhkan untuk menawarkan usuk lebih banyak dan tidak efektif.

2) Tidak ada sistem stok usuk yang banyak, sehingga ketika ada pemesanan yang bersamaan maka dengan jumlah yang banyak maka sering terjadi keterlambatan produksi sehingga penyerahan usuk pesanan menjadi sering terlambat.

3) Masalah kendali mutu produk masih belum ada dengan baik sehingga beberapa produk ketika diserahkan pada konsumen masih ada usuk yang pecah dan dikomplain oleh konsumen. Produk usuk juga yang membutuhkan pengikatan yang baik akan digunakan tali ikat yang kuat sehingga dapat menghasilkan usuk bambu yang tidak mudah pecah.

4) Tidak ada pembukuan yang tertib dan disiplin dari hasil penjualan tersebut sehingga tidak bisa diketahui dengan jelas apakah usaha tersebut untung atau rugi dan kalau untung seberapa besar untungnya. Kondisi hal tersebut juga tidak bisa terlepas dari adanya tidak terpisahnya antara keuangan usaha dengan kebutuhan keluarga.

\section{Permasalahan Mitra}

Pada dasarnya permasalahan yang dihadapai mitra sangat beragam dan saling terkait antara permaslahan yang satu dengan lainnya. Namun demikian untuk mempermudah solusinya, maka permasalahan mitra dikelompokkan menjadi dua aspek utama yaitu permasalahan produksi dan permasalahan manajemen.

\section{a) Permasalahan Produksi}

Walaupun dari hasil analisis situasi ke dua mitra mempunyai kondisi yang sedikit berbeda, namun setelah ditelaah lebih seksama maka secara garis besar permasalahannya yang terjadi hampir sama. Permasalahan produksi teridiri dari:

1) Masalah proses penghalusan usuk bambu yang kurang bermutu dan membutukan waktu lama. Hal ini disebabkan oleh peralatan yang kurang berfungsi maksimal. Dengan peralatan yang ada kualitas maupun produktifitas hasil pembelahan bambu masih rendah.

2) Masalah penghalusan permukaan bambu dengan menggunakan sabit kecil masih menggunakan manual. Tenaga manusia untuk menghaluskan hasil pembelahan bambu dengan cara manual tidak bisa menghasilkan mutu yang bagus dan cepat. Hal ini disebabkan oleh faktor manusia seperti kelelahan dan kejenuhan sehingga akan terjadi penurunan mutu.

b) Permasalahan Manajemen 
Permasalahan manajemen untuk kedua mitra adalah:

1) Masih menggunakan sistem pemasaran konvensional dengan menawarkan dari desa ke desa atau sistem door to door. Informasi produk hanya sebatas bisa diketahui dengan mendapat informasi dari mood to mood atau dari tetangga ke tetangga yang lain desa. Cara ini sangat membutuhkan waktu banyak dan tidak efektif.

2) Masalah kendali mutu produk, belum adanya kendali kualitas produk yang bisa menjamin mutu produk. Usuk bambu yang diserahkan ke konsumen kadang terkesan asal jadi sehingga ketika diserahkan ke konsumen bila ada usuk yang pecah produk terjadi komplain.

3) Belum dilakukan pembukuan yang tertib, arus kas masih tidak jelas, tidak ada neraca bulanan, dan sejenisnya, bahkan masih belum dibedakannya antara keuangan usaha dengan kebutuhan keluarga sehari hari. Hal inilah yang menyebabkan pengembangan usaha masih tersendat sendat.

\section{METODE PELAKSANAAN}

Untuk mencari solusi masalah yang dihadapi oleh mitra metode pendekatan dilakukan sesuai dengan masing masing permasalahan, baik yang menyangkut produksi maupun manajemen.

\section{Solusi Yang Ditawarkan}

Untuk masalah produksi maka pendekatan yang ditawarkan untuk menyelesaikan persoalan tersebut adalah:

1) Pendekatan yang dilakukan untuk menyelesaikan masalah penghalusan bambu yang bentuk dan arah penghalusannya kurang halus maka solusinya adalah dengan membuat alat yang mampu mempercepat proses penghalusan dengan cepat dan baik. Untuk itu maka dibuat alat penghalus usuk bambu. Dengan penghalus bambu menggunakan mesin listrik, maka bentuk bambu yang akan dibelah dengan mudah untuk dikerjakan dengan cepat dan mutu lebih bagus.

2) Pendekatan yang dilakukan untuk mengatasi masalah kekurangan peralatan manual yang memakan waktu lama dan mutu yang kurang, maka solusi yang dilakukan adalah dengan menambah peralatan manual yang mampu bekerja dengan cepat dan baik. Untuk itu solusinya adalah dengan menambah peralatan palu, gergaji, sabit, pahat dan kapak.

Untuk masalah manajemen maka pendekatan yang ditawarkan untuk menyelesaikan persoalan adalah:

1) Masalah sistem pemasaran konvensional dengan door to door bisa diselesaikan dengan membuat informasi produk yang mudah diakses oleh konsumen. Untuk itu solusi yang ditawarkan adalah dengan membuat informasi produk pemasaran berbasis papanisasi/brosur. Cara ini pada awalnya masih dibantu dengan cara pemasaran konvensional tapi tentunya dengan memberikan alamat pada papanisasi produk yang ditawarkan. Dengan demikian maka konsumen dapat melihat dan mengikuti perkembangan jenis usuk bambu serta harganya di papanisasi/brosur, maka konsumen akan lebih mudah untuk mendapatkan informasi produk dengan cepat.

2) Masalah pembukuan, pendekatan yang dilakukan untuk menyelesaikan masalah ini adalah dengan membuat SOP (standard operating prosedure) tentang langkah langkah dalam proses pembukuan. Mitra diberi pemahaman dan dilatih cara melakukan pembukuan yang baik.

\section{Rencana kegiatan}

Rencana kegiatan yang berupa langkah langkah solusi untuk mengatasi masalah produksi dan manajemen adalah sebagai berikut:

1) Koordinasi dan diskusi antar anggota tim dengan mitra. Hal ini dimaksudkan untuk mendapatkan masukan dan gagasan yang digunakan untuk implementasi program ini. Penyamaan persepsi dan langkah gerak dalam pelaksanaan program ini menjadi penting dengan cara kerja yang kolegial seluruh anggota tim dan mitra.

2) Merancang alat beserta spesifikasinya, membuat dan sekaligus uji coba, yaitu meliputi alat:

- Pembuatan alat penghalus usuk bambu

- Penambahan peralatan produksi usuk bambu

3) Merancang dan membuat papanisasi yang memenuhi kriteria perancangan.

4) Pelatihan penggunaan dan pengelolaan pembukuan dan pemasaran kepada mitra. 
5) Pembuatan panduan pembukuan.

6) Pelatihan manajemen kendali mutu produk dan pembukuan keuangan.

\section{Partisipasi Mitra}

Bentuk partisipasi mitra dalam pelaksanaan program ini adalah sebagai berikut:

1) Mitra turut serta dalam diskusi dan memberikan informasi tentang berbagai persoalan dan menyampaikan kesulitan yang dihadapi dalam proses pembuatan alat penghalus usuk bambu maupun manajemennya.

2) Memberikan masukan dalam proses pembuatan alat maupun peralatan lainnya sehingga luaran yang dihasilkan program ini benar benar bermanfaat dan sesuai dengan harapan mitra.

3) Ikut menyiapkan sarana dan prasarana dalam uji coba alat yang telah dihasilkan bersama sama dengan anggota tim.

4) Mengikuti pelatihan dan tutorial yang diadakan sehingga mengerti tentang aspek produksi dan manajemen, baik itu tentang penggunaan pembukuan.

5) Bersedia bekerja sama dengan tim secara berkelanjutan bilamana diperlukan.

\section{HASIL DAN PEMBAHASAN}

Hasil yang dicapai dari pengabdian bagi masyarakat maka secara umum hasil yang dicapai ini dapat diselesaikan sesuai dengan target luaran yang telah di tetapkan. Hasil yang capai dengan melihat dari pekerjaan akan dilakukan bertahap sesuai urutan-urutan yang telah di tentukan, dalam melakukan pekerjaan luaran ini di harapkan tidak boleh saling mendahului, demi keberhasilan dalam program iptek bagi masyarakat ini.

Hasil yang dicapai dari program ini adalah :

1. Pembuatan alat penghalus bambu yang dapat digunakan untuk menghaluskan bambu utuh menjadi usuk yang halus sehingga dalam pembuatan usuk bambu tidak menjadi kendala dalam proses produksi. Alat penghalus usuk bambu memiliki spesifikasi sesuai dengan yang dibutuhkan oleh mitra.

$$
\begin{array}{ll}
\text { - Besi kanal u } 5 \text { x } 8 & \text { - Rumah pisau planer } \\
\text { - Plat eiser besi 10 mm } & \text { - Pisau } \\
\text { - As besi 1 1/2" } & \text { - Thinner A special } \\
\text { - Pully besi 6 “single } & \text { - Dempul duco } \\
\text { - Pulley besi 6" double } & \text { - Mesin Honda GX200 } \\
\text { - Pillow blok + bearing } & \text { - Fan belt A 52 }
\end{array}
$$

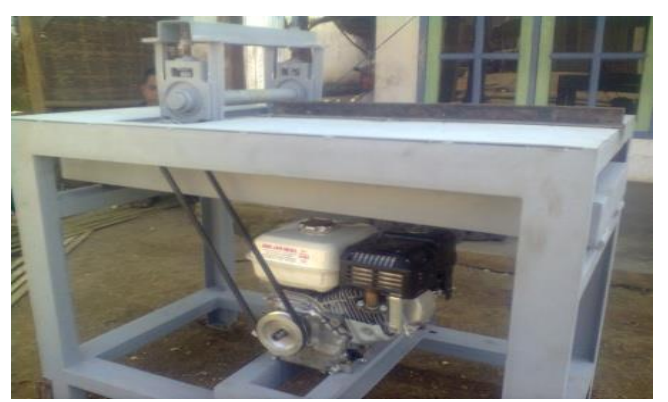

Gambar 6. Alat Penghalus Usuk Bambu

2. Pelatihan sistem pengelolaan keuangan dalam pengrajin usuk sehingga semua transaksi dapat tercatat dan teranalisa dengan baik.

3. Pelatihan pemasaran dalam pengrajin usuk sehingga semua transaksi dapat tercatat dan teranalisa dengan baik.

Rencana tahapan pengabdian berikutnya adalah sebagai berikut :

- Pendampingan dalam hal pembukuan dan pemasaran dalam upaya untuk peningkatan produksi usuk bambu

- Pendampingan dalam hal Implementasi alat penghalus bambu yang dihasilkan sehingga dapat mempercepat dan memperbaiki hasil produksi usaha usuk bambu. 
- Pendampingan dalam hal mengadakan pelatihan dari alat penghalus bambu tersebut.

\section{KESIMPULAN}

1. Pada dasarnya permasalahan yang dihadapai mitra dua aspek utama yaitu permasalahan produksi dan permasalahan manajemen adalah masalah proses penghalusan usuk bambu yang kurang bermutu dan membutukan waktu lama.

2. Masih menggunakan sistem pemasaran konvensional dengan menawarkan dari desa ke desa atau sistem door to door, masalah kendali mutu produk.

3. Belum adanya kendali kualitas produk yang bisa menjamin mutu produk, belum dilakukan pembukuan yang tertib, arus kas masih tidak jelas, tidak ada neraca bulanan, dan sejenisnya

\section{Ucapan Terima Kasih}

Ucapan terimakasih disampaikan kepada Rektor Universitas Widyagama Malang beserta jajarannya; Ketua LPPM Universitas Widyagama Malang beserta staf yang sudah memfasilitasi proses pengabdian masyarakat ini dari sejak proposal hingga terlaksananya kegiatan.

\section{DAFTAR PUSTAKA}

Andy Widyowijatnoko Mustakim. Modul Pelatihan Konstruksi Dinding Bambu Plaster, Departemen Arsitektur, Institut Teknologi Bandung.

Bagus Dwi Hirmawan, Etty Kurniawati, Maya Indriyani (2010), Pengawetan Bambu Dengan Alat Buchery-Morisco Menggunakan Pestisida Nabati Campuran Ekstrak Biji Mimba Dan Filtrat Umbi Gadung Sebagai Bahan Pengawet Bambu Ramah Lingkungan, PKM-GT, Universitas Negeri Malang.

Direktorat Penelitian dan Pengabdian kepada Masyarakat, DIKTI, 2013. Panduan Pelaksanaan Penelitian Dan Pengabdian Kepada Masyarakat Di Perguruan Tinggi Edisi IX.

Elizabeth A. Widjaja, Karsono (2005), Keanekaragaman Bambu di Pulau Sumba, Jurnal Biodiversitas Vol. 6, No. 2, April 2005, hal. 95-99, ISSN: 1412-033X.

Mery Natalia Nadeak. (2009) "Deskripsi Budidaya Dan Pemanfaatan Bambu Di Kelurahan Balumbang Jaya (Kecamatan Bogor Barat) Dan Desa Rumpin (Kecamatan Rumpin), Kabupaten Bogor, Jawa Barat” Skripsi, Fakultas Kehutanan, Institute Pertanian Bogor. 